\title{
The Use of Social Media in the Student Activist
}

\author{
Matang Matang and Samsuri Samsuri \\ Program Studi Pendidikan Pancasila dan Kewarganegaraan \\ Pascasarjana, Universitas Negeri Yogyakarta \\ Yogyakarta, Indonesia. \\ matang.2016@student.uny.ac.id
}

\begin{abstract}
Student activists play an important role because it is first ranked in the category of Internet usage at the types of workers in the use of social media not only as a social tool, social media is widely used as a tool of social movements, increase income, and new forms of political participation. This qualitative research examines the utilization of social media by student activist from 4 association of civic education students in Yogyakarta. The results showed that the type of social media most often used student activist is Instagram and Facebook. The organization of student groups in which they work using social media tends to display the activities they will and have done, as well as promotional events such as seminars and book review. Student activists use social media for the existence of identity, as entertainment, place of sale and political participation. These findings provide a way for further research to further examine the activities of student activists in social media. Social media is a new form of political participation of student activists. These findings provide a way for further research to further examine student activist activities in social media.
\end{abstract}

Keywords- social media; student activist; political participation

\section{INTRODUCTION}

The world is increasingly exposed by the internet, especially social media. It is marked by the number of internet users. We Are Social report, in January 2017 revealed that total of 7,476 billion people in the world, more than half $(3,773$ billion) use the internet. In Indonesia, reports from We Are Social are suitable with the report of the Indonesian Internet Service Providers Association (APJII) Survey. Most Indonesians use the internet. All of the total population of Indonesia 256.2 million people, $51.8 \%$ (percent) use the internet. Social media being the most visited by netizens is Facebook, Instagram, twitter, and you tube $[1,2]$.

Results of previous research indicate that social media is a new form of youth political participation and a reference source to political events [3]. In addition to the objectives of political participation, the motive for the usage of social media by student activists is the update of information and motives of entertainment [4], increase income by personally and managemently [5].

The needs of students on social media can't be denied, especially the identity of the millennial generation. Social media in students can support academic performance [6], political participation [7,8], and as a life-long learning by sharing information every day [9].

Seeing the development of social media is certainly inseparable from the issue of civic citizenship education affiliated to the establishment of good citizens and participatory rights and obligations [10]. The network of students who studied directly from the department of civic education in Yogyakarta. Yogyakarta is one of the provinces in Indonesia that has long been widely known by the public with the nickname "city of education" [11]. In Yogyakarta there are 4 campuses that have civic education program that is in Yogyakarta State University, Cokroaminoto University Yogyakarta, Ahmad Dahlan University, and Universitas PGRI Yogyakarta.

\section{Social MEDia AND StUdENT ACTIVISTS}

Pierce \& Schwartz describes the personality of student activists as flexible, acceptable, unconventional, tolerant, restless, tends to rebel, and expressive person [12]. So they are critical of the government's policy to fight for justice for all elements of society, especially the middle to lower economy. The Internet gives space for citizen participation [13]. Then, this space is used by student activists in conveying their views on public issues. Social media mediated student participation on campus [14]. Social media can be used to share information $[15,16]$, promoting transparency and change [17], enhancing the effectiveness of transparency and accountability [18], social media is part of the mass media can increase student political participation [19] and other benefits such as increasing income, self-existence, and entertainment.

Social media becomes a space of participation for student activists to come together and build community, broaden and encourage the form of participation [20-22]. This is a new avenue of engagement that offers a wide range of positive and significant opportunities to participate in demonstrations. Social media creates new forms of protest in democratic life.

\section{A. Student activists as a picture of the future of a nation}

Students who are active in the activities that exist in the campus and actively respond to the problems that occur in this community is called student activist [23]. Student activists are generally understood to show the sound of individual or collective students demanding social change. This concept is often used alternately with student protests, student rebellion, student politics, student movements, and student disturbance. 
Furthermore, Byaruhanga, one of the main reasons for student activism is the awareness of their status, as well as their sense of duty to be the conscience of the public, especially on issues of public concern, such as democracy and accountability of leaders and constituents [23].

This student movement was ignored because of their minority's existing status. Although this movement is a minority, they can make changes and invite up to collect mass. The activist movement has not only had a significant impact on the university, but it sometimes creates social unrest and sometimes revolution [23,24]. They are the groups most responsive to changing conditions and are critical to advocating for social transformation. Therefore, the movement of this students will continue to be intertwined and continues on the condition of the struggle of modern forces. As students who are campus to gain knowledge are prospective leaders and leaders in the life of the state, the agent of change, and people who have intellectual and future ideals.

\section{B. Positive and negative impacts of social media in the hands of students}

The use of social media has implications, as well as the concept of "social media addiction" described by Huang [25]. Social media addiction identified as often selfish, relaxed and often bored, preoccupation, negative emotions, and loss of interest in social activities. Gratification of social media is a risk factor to the occurrence of addiction, the satisfaction of entertainment and information that bridges the characteristics of sociopsichological adolescents in social media addiction.

Korpijaakko describes loss to individuals, users will be lonely or isolated from the real world because it is always on fake community connectivity [26]. On the other side because of hyper-connectivity, when there is no connection they will be agitated. The psychological consequences of unhappiness compare the others life. And other weakness such as pressure, fatigue, waste of time, and exploited personal identification, even addiction. It correlates about low self-esteem (narcissism). Disadvantages to the community, the creation of gated communities that keep away from meaningful relationships and affect relationships by offline. Disadvantages to socio-culture, claims of profit for socio-culture are not translated in the form of real change. So, we need to maintain social movements. Although it can't be denied, the use of social media in other studies also mentions that students use social media only for their entertainment and communication. Social media is not enough to provide motivation for educational purposes [27].

Haenschen the wide adoption of Internet offers a real potential for increase political participation through the dissemination of digital reminders to vote [28]. Korpijaakko it describes the benefits to individual, as a personal identity presentation, further cover of the photo on profile page can be used as a portfolio to find work [26]. Benefits to the community, increase relationships to others, increase social capital through strong relationships will affect to larger communities. Benefits to socio-culture, the social benefits associated with using Facebook are the expansion of democracy, increase political and social awareness, and creating change.
In some instances social media makes social connections with others. Wyrwoll describes the benefits of social media as a social media source, social media empowering civil movements, social media facilitates ethical consumerism, social media supports word-of-mouth, and social media extends market research [29].

\section{Social media and change role}

Students play an important role in a change. The changes made by the students to the level of the government dropped as in the case of Indonesia's reform in 1998 [23]. Students who are dominated by the young generation who enjoy the present generation and will indirectly inherit the future government. Transfer of power from the old government to its successors is inseparable from the student's political participation as a form of democracy that is being undertaken.

Mossberger, Tolbert, and McNeal see the ability to participate in the online society (Digital citizenship) regularly and effectively establish information literacy competencies, the ability to participate as democratic citizens, increase economic opportunities, and increase participation political [30]. The results of the Valenzuela, Arriagada, and Scherman studies contribute our concept about the role of social networking sites in the evolving political and democratic changes [31]. Social media mediates the major changes was occurring within a State. Arab Spring has become an obvious example of social media being a tool of conveying message to a wider society by forming a demonstration movement making a major change in the country [32].

\section{METHOD}

The type of research that will be used in this research is analysis text in the form of qualitative. Qualitative is used for the purpose of understanding and exploring how social media utilization conducted by student citizenship in Yogyakarta. The research was conducted on campus which has civic education program, namely Yogyakarta State University, Cokroaminoto University of Yogyakarta, Ahmad Dahlan University, and PGRI University of Yogyakarta. The subjects of research are student activists who participate in the management of student organizations such as the student association of civic education program in Ahmad Dahlan University, the association of citizenship and law students of Yogyakarta State University, the student association in Cokroaminoto University of Yogyakarta, and the association of students in civic education program PGRI University of Yogyakarta. It consists of the chairman, assistant and coordinator of each division of 22 students. Information or data collected and analyzed consists of interviews, observations, and documents. Next, look at the social media account activity (Facebook, Instagram, twitter, and you tube) civic education student activism in the form of status updates or share links (text, photos, and videos), and other activities such as commenting on friends and public issues. The results are presented in qualitative descriptive form.

\section{RESULT AND DISCUSSION}

The result of interview on the board of 4 student organization of civic education are in the student association of 
civic education program in Ahmad Dahlan University (HMPS PPKn UAD), the association of citizenship and law students of Yogyakarta State University (HIMA PKnH UNY), the student association of Cokroaminoto University, HMJ PPKn UCY), and the association of students in Civics Education Program in PGRI University of Yogyakarta (HMP PPKn UPY). It found that student activists all already have social media accounts.

The types of their social media usually use Instagram and Facebook. Other findings at the usage of social media that student organizations where citizenship education activists work (HMPS PPKn UAD, HIMA PKnH UNY, HMJ PPKn UCY, and HMP PPKn UPY) are also active in using social media especially Instagram.

Social media adoption is significantly driven by three types of categories. First, personal needs consists of fun and entertainment. Second, social needs consists of social influences and interactions. And the third is the release of tension, it consists of a sense of belonging, friendship, and playfulness [33]. The significant adoption of social media for the community also occurs on PPKn student activists in Yogyakarta. Student organization tends to display on every status update or posting on social media account in the form of information on student organization activity, event promotion activities such as seminar and book review. There are two important elements of social media that make student activists and student organizations use it [34].

First, using social media is easier to access information and also easily publish text, images, video, or audio even without great technical knowledge. Second, social media allows to interact with each other users. Student activists use social media by updating their daily life status. Photos or videos by adding some text in the form of activity description. There is also a text of motivation, criticism, and propagation. Another activity of student activist on social media is to share links (text, photos, and videos) in their account or retweet someone else. Mastrodicasa \& Metellus the purpose motives of the use has been experienced by student activists such as searching and updating information, motives of entertainment and political participation [4]. The results of this analysis can be seen on Instagram \#maharanideka account showing the demonstration activities that have been done. Social media accounts \#atiqahhasanah show participation on Human Rights day. Twitter account \# EllyNR17 agrees that corruption should be eradicated, by retweeting the twitter account of the Corruption Eradication Commission. Attractive text is always used by Instagram \#din7116 account by using AnaktiriUCY hastag as a criticism of campus policies that are not aligned with students. New ways to engage in civic action are presented by Mihailidis $\&$ Thevenin [21], in the context of online advocacy, protest activities can be done by liking, sharing, and combining them in social media.

The new way of engagement offers wide opportunities for new and innovative approaches to teaching and learning about political engagement in the context of social media and technology platforms. This combines is a new model of citizen engagement and political participation with a framework for developing active, and participatory citizenship. Student activists in this study demonstrate the identity of digital citizenship in which the adoption and use of internet especially social media has been done in everyday life. The act of citizenship is seen in the political participation of student activists in responding to the public problems that occur in society. As Rice, et al., online activities in social media as a form of student involvement in expanding and encouraging a form of political participation and the other participation especially in political action [20]. Social media is also used to sell like Facebook account \#Annisa Tusya Frida. The result of Guesalaga research shows that there is acknowledgment that social media can benefit from the sale, either personal or management [5]. Furthermore, customer involvement with social media also predicts the effectiveness of promotions and offers made in social media in terms of sales. This trend is also used student activists assess the popularity of a clothing to sell in social media.

Student activist activity is very diverse in social media. Knowledge, environmental conditions, interests, and motivations affect how they use and maximize it. Political participation is reflected through the activities of student activists by commenting directly on social media accounts of government officials and campus officials. Status updates in the form of photos or videos by giving text descriptions are also done as a form of participation against the injustice they get.

\section{CONCLUSION}

Student activists become a reflection of a large group of students. They are identical to people who are actively involved in campus activities. So, frequently from this small group can give a big influence on the others. Such as demonstrations of public problems. Social media as one of characteristics in the millennial generation can not be separated from students, they are the next generation of nation and state. The results show that all student activists of civic education in Yogyakarta have social media accounts. The other findings, the organization of student associations where they work also have social media. The social media of the student group organization tends to display the their activities will and have done, as well as promotional events such as seminars and book review. The most common types of social media used by student activists are Instagram and Facebook. Student activists use Instagram and Facebook for the existence of identity, as entertainment, place of sale and political participation. These findings provide a way for further research to further examine student activist activities in social media.

\section{REFERENCES}

[1] Asosisasi Penyelenggara Jasa Internet Indonesia: http://www.apjii.or.id/survei, di akses tanggal 27 Desember 2017.

[2] We Are Social: https://wearesocial.com/special-reports/digital-in-2017global-overview, di akses tanggal, 27 Desember 2017.

[3] Olsson, T. (2016). Social media and new forms for civic participation. New Media \& Society, 18 (10), 2242-2248.

[4] Mastrodicasa, J. \& Metellus, P. 2013. The Impact of Social Media on College Students. Journal of College and Character, 14 (1), 21-30.

[5] Guesalaga, R. 2016. The use of social media in sales: Individual and organizational antecedents, and the role of customer engagement in social media. Industrial Marketing Management, 54, 71-79. 
[6] Al-Rahmi, W. M., Othman, M. S., \& Yusuf, L. M. 2015 The role of social media for collaborative learning to improve academic performance of students and researchers in Malaysian higher education. International Review of Research in Open and Distributed Learning, 16 (4), 177-204

[7] Scherman, A., Arriagada, A., \& Velenzuela, S. (2014). Student and environmental protests in chile: the role of social media. Politics, 35 (2), 151-171

[8] Tang, G. \& Lee, F. L. F. 2013. Facebook use and political participation Social Science Computer Review, 31 (6), 763-773.

[9] Bode, L. 2016. Political news in the news feed: learning politics from social media. Mass Communication and Society, 19 (1), 24-48.

[10] Wiranataputra, U. S. 2012. Pendidikan kewarganegaraan dalam perspektif pendidikan untuk mencerdaskan kehidupan bangsa Bandung: Widya aksara press.

[11] Soekiman, D. 1986. Sejarah Kota Yogyakarta. Jakarta: Departemen Pendidikan dan. Kebudayaan.

[12] Pierce, R. A. \& Schwartz, A. J. 2010. Personality Styles of Student Activists. The Journal of Psychology, 79 (2), 221-231.

[13] White, C. W. 1997. Citizen participation and the internet: Prospects for civic deliberation in the information age. The Social Studies, 88 (1), 23 28 .

[14] Loader, et al. 2015. Campus politics, student societies and social media. The sociological riview. 63, 820-839.

[15] Osatuyi, B. 2013. Information sharing on social media sites. Computers In Human Behavior, 29 (6), 2622-2631.

[16] Panahi, S., Watson, J., \& Partridge, H. 2015. Information encountering on social media and tacit knowledge sharing. Journal of Information Science, 42 (4), 539-550

[17] Bertot, J. C., Jaegar, P. T., \& Grimes, J. M. 2010. Using ICTs to create a culture of transparency: E-government and social media as openness and anti-corruption tools for societies. Government Information Quarterly, 27 (3), 264-271.

[18] Stamati, T., Papadopoulos, T., \& Anagnostopoulous, D. 2015. Social media for openness and accountability in the public sector: cases in the greek context. Government Information Quarterly, 32 (1), 12-29.

[19] Novianasari, D. dan Samsuri. 2016. Peran media massa dalam meningkatkan partisipasi politik para aktivis HMP PKn di Yogyakarta. SOSIA, 13 (2), 13-29.
[20] Rice, L. L., Moffett, K. W., \& Madupalli, R. 2012. Campaign-related social networking and the political participation of college students. Social Science Computer Review, 31 (3), 257-279.

[21] Mihailidis, P \& Thevenin, B. 2013. Media literacy as a core competency for engaged citizenship in participatory democracy. American Behavioral Scientist, 57, 1611-1622.

[22] Musgrave, M. L. 2015. Digital citizenship in twenty-first century young adult literature: imaging activism. New York: Palprave macmillan.

[23] Byaruhanga, F. K. 2006. Student power in Africa's higher education: A Case of Makerere University. New York \& London: Routledge.

[24] Altbach, P. G. 2007. Student politics: activism and culture. In Forest, J J. F. \& Altbach, P. G. (Eds.), International Handbook of Higher Education. (pp.329-345). Netherlands: Springer.

[25] Huang, H. 2014. Social media generation in urban china: a study of social media use and addiction amon adolescents. New york: Springer.

[26] Korpijaakko, M. L. 2015. Cracking facebook: The importance of understanding technology-based communication. Rotterdam: Sense publishers.

[27] Ahmed, S. S. \& Hassan, A. (2017). A Study on the rationale of social media use by the students of King Khalid University. English Language Teaching, $10(8), 43-50$.

[28] Haenschen, K. 2016. Social Pressure on Social Media: Using Facebook Status Updates to Increase Voter Turnout. Journal of Communication, $66,542-563$.

[29] Wyrwoll, C. 2014. Social media: Fundamentals, models, and ranking of user-generated content. Hamburg: Springer.

[30] Mossberger, K., Tolbert, C., \& McNeal, R. 2008. Digital citizenship: the internet, society, and participation. London: The MIT Press.

[31] Valenzuela, S., Arriagada, A., \& Scherman, A. 2012. The Social Media Basis of Youth Protest Behavior: The Case of Chile. Journal of Communication, 62, 299-314 .

[32] Wolfsfeld, G., Segev, E., \& Sheafer, T. 2013. Social Media and the Arab Spring. The International Journal of Press/Politics, 18 (2), 115137.

[33] Zolkepli, I. A. \& Kamarulzaman, Y. 2015. Social media adoption: The role of media needs and innovation characteristics. Computers in Human Behavior, 43, 189-209.

[34] Schmidt, J. H. 2013. Social media. Wiesbaden: Springer VS 